\title{
Dialectics, Esotericism and Evolutionism in 20th Century Pedagogy. On the Totalitarian Heritage in the Educational Concepts of Cultural Education, with Maria Montessori, Rudolf Steiner and Pavel Blonsky
}

\author{
EHRENHARD SKIERA \\ Europa Universität, Flensburg
}

In the following contribution it will be shown that and how the theocratic heritage has perpetuated itself in more or less changed form in newer educational theories. Its transformation can be understood as its secularization, which passes on the absolute as epistemological totalitarianism in the form of violence, provided that it was armed with power of action. As examples here serve the multifaceted cultural or humanistic pedagogy ("Kulturpädagogik" or "Geisteswissenschaftliche Pädagogik" - GP), which is still important today, as well as three important concepts of reform pedagogy (respectively the "New Education Movement"), namely those of Maria Montessori, Rudolf Steiner and Pavel Blonsky.

Key terms: Dialectics; Esotericism; Evolutionism; Cultural Education; New Education Movement; Maria Montessori; Rudolf Steiner; Pavel Blonsky

\footnotetext{
PRELIMINARY REMARKS: ON THE ENTANGLEMENT OF DIFFERENT MODES OF THINKING AND ITS POLITICAL-PRACTICAL CONSEQUENCES

When we deal with historical and systematic questions, we are dependent on sufficiently precise, i.e. differentiating terms. However, in order to understand complex traditions of thought and social dynamics, it is also necessary to maintain an awareness of diverse interdependencies, i.e. the possible mental "osmosis processes". A way of thinking is not available as an isolated one par excellence. Central motives appear - partly in specifically adapted form - in different worldviews.
} 
With regard to the thought traditions of dialectics, esotericism and evolutionism mentioned in the title of this article, there are similarities both in formal-epistemological and content terms. The modern dialectics (of Hegel's coinage, later Marx-Engels') claimed to have found the scientifically certified key for the historical development. Its own epistemological subject of knowledge, however, does not come from empirical science or an epistemological philosophy of the Enlightenment, but is based on the centuries-old tradition of esoteric-religious thinking: as the conviction that man can generate absolute, "true" knowledge by means of direct access to the "higher" knowledge or by the access mediated by experts. In the 19th century, this grandiose epistemological self-image was combined with the idea of development. The thought figure of the development respectively the higher development of man as well as the thought of the further development or even perfection of society as a whole has left deep imprints in almost all newer worldviews. But man as homo sapiens et faber was not prepared to leave development to chance or to free fate. He felt compelled to play energetically into the hands of the Great Telos, to minimize or even completely eliminate the coincidence and contingents of life, and thus to secure progress. Thus a peculiar, missionary-martial dynamism is inscribed in the ideological concepts in question, namely as an archaic struggle with the aim of achieving the final, total victory: the victory of one social class over the other (dialectical materialism); the victory of light over the powers of darkness or of good over evil/bad (esotericism); the victory of the more highly developed human being or the more highly developed races over their backward and inferior forms (fascism).

Only by combining quasi-scientific and instrumental-technological knowledge with teleological-evolutionary concepts as well as with corresponding personal representations (convincing "spokesmen" in philosophy and charismatic "leaders" in politics) could powerful social movements be formed. The corresponding worldviews, as far as they develop historically and politically, in their function as doctrines of salvation meet man's longing for harmony, security, prosperity, happiness. In the hopeful beginning, which seemed to be still human-friendly, the new world views also satisfy the longing for freedom and self-determination.

Pedagogy and politics have always been based on transcendental normative, i.e. absolute values. After the dwindling of religious interpretive sovereignty in the 19th and 20th century, these values were then proclaimed as manifestations of truth that were objective in the scientific sense and necessary for teleological history. Since there can be no generally binding interpretation of the truth in our heterogeneous world, confrontations between the various factions of the Absolute were and are inevitable.

In the conflicts of the 20th century, the socialist-communist faction and the fascist faction proved to be the most politically momentous - with serious psychological, political and social effects to the present day. For the enthronement 
of a heuristic invention - namely the dialectical method or the idea of higher development - as a "supraindividual", all-determining factor of history, brought a martial quality into the conflicts that was hitherto unknown in its extent. Before dialectics or evolution were elevated to the status of a historical-concrete mechanism of action and militarized, they remained in the (largely) peaceful space of Socratic-scholastic or philosophical discourses. Only in socialism/communism (in Russia), just a few years later then also in fascism (Italy and Germany) the protective border between individual and society is removed in the name of dialectical or fateful powers and "progressive" development goals. In both cases it is a matter of a materialistic-technological dialectics of the real extermination struggle against the intrapsychic opponent (i.e. against the "false consciousness") as well as against the declared enemies in the inner and outer space of the respective sphere of power, which is determined differently in terms of content. And in both cases the real dictatorship - of the proletariat respectively of the higher race or the higher culture - is preceded by an epistemological dictatorship: as an unconditional and power-supported prescription to perceive and interpret the world according to the prevailing principles.

The pedagogy of the twentieth century moves over long stretches in the socio-cultural field of tension of totalitarian imprint that has just been outlined. Even the pedagogy of the humanities ("Geisteswissenschaftliche Pädagogik"), which is declaredly based on historicity and thus on the relativity of thought and action, is decisively influenced by this. This is - presumably - an important reason why some prestigious representatives of this "bourgeois" pedagogical approach could not resist the bewitching sirens of fascism. This has its deep reasons in the history of ideas, which - in the end - refer to archaic theocratic thinking and its secular metamorphoses in totalitarian worldviews.

\section{INTRODUCTION: FROM THE DIVINE TO THE HUMAN DESTINY OF THE EDUCATIONAL AND ITS CRYPTO-THEOLOGICAL IMPLICATES}

The revaluation of the concrete, sensual experience in early modern times had to lead to the critical question of God's position towards the world and in the world. For with this revaluation is connected a movement of thought which calls into question the truth and binding nature of the traditional answers. This also includes the question of man's position towards God, towards himself and towards the world.

In cultural history it is not always possible to give a relatively precise date on which a revolutionary idea is formulated. But this is possible with regard to the theological question about the remaining task of God in a world far from God, a world of empiricism, science and technology. There has been scepticism about systems of a comprehensive world interpretation since antiquity. But the Florentine philosopher Giovanni Pico della Mirandola now also refers this doubt 
to the fundamental constitution of man and society.

At a time when the power of religion was still almost unbroken, in 1486, Pico argued in his speech "On the Dignity of Man" that man must give himself the laws of his actions in free consultation and with his free will. He justified this with the fact that in contrast to the other creatures of God no firm laws of his action were given to the human being. Pico reinterprets the shortcoming of man's imperfection due to creation as an anthropogenic and social task desired by God. The solution to this task, that is what is really provocative in Pico's message, can now no longer be based on the Divine Will. At the same time this means an ontological deficit which the transcendental dogmatist can only perceive as a severe insult and attack on his ideal self-image. For it doubts or negates the possibility that there can be a transcendental-objective subject of knowledge at all that could grasp the absolute truth. Implicitly but clearly, Pico formulates an axiom (as non-dogmatically bound thinkers assume today: an axiom that cannot be deceived), on which the philosophy of the following centuries, above all its practical section, still works: that in the determination of the human and in the social there are no values rooted in the transcendent, respectively no absolute regulations.

To overcome the ontological deficit as well as to reverse the epistemological insult, and to generate and bring to effect true knowledge no longer anchored in God, but nevertheless "somehow" in the Absolute - that remains an impulse for the philosopher and the politician. Seen purely systematically (or ideologicallyconstructively), such an undertaking can only be successful if it succeeds in finding what should be in being and then convincingly presenting what was found as the "true" knowledge free of prejudices and assumptions. This difficult task is often solved by shifting the transcendental normative, originally dormant in God, prescriptively (or "inscriptively") into being, so that being distant from God or (as with materialists and atheists) of godless character may continue to be and remain. In this way, ethics can be re-ontologized. However, the skeptic will want to expose this procedure as circular reasoning. In his opinion, what is laboriously found by speculation is hidden before the search by the seeker himself in the social realm. Notwithstanding the impudent criticism, all teleologicaleschatological world designs follow this logical (or logistic) procedure. This applies mutatis mutandis even to the popular modern social philosophies of Bloch's or Habermas's provenance, in other words to a dialectically founded philosophy of hope, and to the discourse ethics of the domination-free exchange of rational arguments (cf. Borst, 2017; in: Németh et. al., and Wellmer, 1986). Both thinkers postulate a "should" present in social practice, as it were embedded in the "in-between", in the "we-us" (Habermas) respectively as the "concrete utopia" (Bloch) of a better, ultimately just and philanthropic world.

According to form and content it is a normative-chiliastic moment, the signs of which can and should be sought out, recognized, grasped and brought to effect and perfection through discourse and action in the social world. 
Pedagogy, too, makes use of the process of seeking the unconditional should in real life. If it does not remain anyway in the religious-normative tradition i.e. in the specific frame of reference of religious dogmatics and its institutional manifestations - it tries to generate the transcendental and absolute of its theorems and prescriptions in another way. It does this above all in connection with parallel philosophical movements by pursuing the restitution of the religious in a new, enlightening guise (often perhaps unconsciously and unintentionally). Here the rhetorical invocation of "freedom", "autonomy", "individuality of the child", "human dignity", "personality", "emancipation" and the like, i.e. the positively connotated vocabulary of the Enlightenment, plays an important, legitimatory role. These terms, which at the first glance appear "philanthropic", serve in theory production as empty formulas that are linked with the contents of the respective own semantics and objectives - as just indicated by circular conclusions that are not always easy to decipher; or by naive epistemological (e.g. Steiner - see below) or additionally concrete-political fantasies of omnipotence (e.g. Blonsky and his philosophical and political advocates - see below). Because the terms themselves are neither obvious nor self-evident, their actual meaning can only be determined by means of historical-systematic context analysis (some examples below). Philosophy, like pedagogy, finds (or invents) various surrogates of God for the purpose of compensating the ontological deficit and the epistemological grievance, with the help of which a "somehow" decisive token is to be saved. From Immanuel Kant we know the "moral law" in us, in which he despite his sceptical attitude towards knowledge believes as firmly as in the laws of the "starry sky" above us. Morality is thus ultimately to be justified by the use of reason with a certainty that corresponds to the empirical evidence of the laws of nature. Hegel invents the mechanism of dialectics and identifies the "objective mind/spirit" as the subject of history. Thus Hegel "saves" the Holy Spirit from the original Trinity of God. Karl Marx and his numerous pupils see the dialectical mechanism (as dialectical materialism) at work both in nature and in society, and whoever has understood both can proclaim the universal "truth" ("Prawda"), can also enforce it by the possession of appropriate means of power. Various energetic ideas (such as Bergson's "élan vital", Nunns and Montessori's "horme") also play a role here in connection with evolutionary concepts as God's substitute forms at the beginning of the 20th century.

The fact that pedagogy is indeed based on a theocratic legacy to a large extent, even in its non-explicitly religious factions, can be demonstrated by looking at various educational concepts, some of which are still significant and highly esteemed today. Even in the variant of cultural pedagogy or humanities education (respectively "Geisteswissenschaftliche Pädagogik" - GP), which is still influential today and which has been shaped by historism, a quasi-theocratic basic trait can be demonstrated. Its epistemological and pragmatic sense consists after the gradual disappearance of the religious power of interpretation (even the theologians speak for a long time of the "death of God"), and in the 
horizon of the rapid social change threatening for very many people, in the establishment of an "unconditional absolute" as target and guideline point of action. Although it knows (following W. Dilthey) about the historicity and thus relativity of the pedagogical, it nevertheless adheres to "supertemporal values" and "supraindividual spiritual powers". - In the 20th century, reform pedagogy can be regarded as the opponent of the GP. It emphasizes - directed against any pedagogical appropriation and against the usual didactic materialism - the inherent right of the child to free self-development, but subjects the child to a higher power just as consistently as the old theocratic pedagogy (and far more so than cultural pedagogy); for it also wants to create the new, pacified society with the New Man under the spell of a specific metaphysics of the spirit (Steiner) or development (Montessori, Blonsky and many others). Despite the rhetoric of his protagonists to the contrary, this great goal can hardly be achieved in freedom or in a quasi-natural way without coercion.

The recourse to the divine, the absolute and the "eternal values" suffice the longing of the ambitious educator to create a space of control in which the allegedly good in the child can be promoted and the allegedly bad can be fought against. This tends to lead to the establishment of a panopticon, a total surveillance institution, as proposed by Jeremy Bentham (in 1787) as an institution for the custody and rehabilitation of delinquents. In a space of maximally optimized education and control, individual interest, personal development and "free" self-development only have a place insofar as they serve the high ideals of the educator or at least do not hinder them. Otherwise, resistance against the resistive is called for. Maria Montessori expresses this in pastoral words to the educators as follows: "Do not be afraid to destroy the bad" (M, 1972. 242. p.).

In the following, the thought process outlined above will be developed in more detail. It will be shown that and how the theocratic heritage has perpetuated itself in more or less changed form in newer educational theories. Its transformation can be understood as its secularization, which passes on the absolute as epistemological totalitarianism in the form of violence, provided that it was armed with power of action. As examples here serve the multifaceted cultural or humanistic pedagogy ("Kulturpädagogik" or "Geisteswissenschaftliche Pädagogik" - GP), which is still important today, as well as three important concepts of reform pedagogy (respectively the "New Education Movement"), namely those of Maria Montessori, Rudolf Steiner and Pavel Blonsky.

The sketch of the concepts could serve as a background for the further question of which starting points a pedagogy must or should recognize that renounces the claim to absolute knowledge and absolutely valid imperatives. The question can only be posed within the framework of the contribution, but not developed in detail. It would be a pedagogy, this is at least hinted at, which tries to deal with uncertainty and contingency, which furthermore respects the fundamental freedom and instrumental unavailability of man, and thus also 
respects the idea of the openness of history and the future. Such a pedagogy would not be subject to the temptation to establish a panoptic control space in the horizon of great human goals.

\section{The CUltural or humanities Pedagogy („KulturpädagogiK“ Respectively "Geisteswissenschaftliche PÄdagogiK" - GP) IN THE HORIZON OF A DIALECTICAL-IDEALISTIC INTERPRETATION OF THE ESSENCE OF EDUCATION}

As a result of the Enlightenment and in the context of the development of a critical historical science in the 19th century, an extremely multi-faceted pedagogical current is rising up against the theologically founded pedagogy, which understands itself first as cultural pedagogy, then as humanities pedagogy ("Geisteswissenschaftliche Pädagogik" - Matthes, 2011).

One of its brilliant achievements is the elaboration of the so-called "historicalsystematic" or "hermeneutic method" for the deciphering of pedagogically relevant texts and other symbols.

Yet despite the awareness of its historicity, this pedagogy ultimately cannot free itself from the shadow of its theocratic opponents - that is, from the advocates of an absolute, theologically founded normativity. Instead of God's plan of salvation, which was previously the responsibility of pedagogues and theologians to follow, "culture" or "objective spirit" now appears on the scene. But also God, the divine, and the religious, also the "historical destiny", the "state", the "people" etc. are often further regarded by the leading representatives of this pedagogical approach as self-evident promoters of absolute normativity. Both Hegel's "objective spirit" as well as the culture of cultural or humanities pedagogy thus ultimately confronts the child as an equally foreign and absolute power, albeit methodically mitigated by the Christian ethics of love and mercy. Theodor Litt, the leading representative of the GP, speaks in this context of the "superior power of the 'objective spirit"', which through its servant - the teacher - does "his articulating work on the still shapeless souls" of the children (Litt, 1949. 51. p. - first edition 1927). Thus the educator as a spiritual servant makes "the eternal content in the contemporary works shine" (ibid.) by presenting the curricular distillates of the high culture to the pupil. Litt's thinking flows into the dialectical educational formula of a reconciliation and union of the individual with the general: "A maximum of binding, connected with a maximum of freedom, this is the miracle which is realized anew in every encounter of ideal contents with spiritual movement" (Litt, 1949. 70. p.).

But the encounter with the "superior violence of the objective spirit" (see above) obviously does not get by without a portion of possibly also bodily violence. I want to illustrate this fact with the concise text by Karel Ozvald, a pupil of Eduard Spranger, who had a lasting influence on pedagogy in 
Slovenia between the wars. He uses the image of the educator-gardener that has been familiar for centuries. He compares his efforts with the cultivation of useful plants, and writes in 1923: "A child, as soon as it is born, is like a wild shoot, whose juices must first be changed by grafting if it is to become a noble rose, $/ \ldots /$ and also in the course of the year it must again and again be trimmed, tied up and cared for, otherwise it would become wild again. The process of ennobling a child is called education; at its core, education is also a kind of struggle with the nature of the pupil" (Ozvald, 1923; quoted by: Protner, 2015). In the diction similar to the statements of other colleagues from the GP community, and as we will see in a moment also of some reform pedagogical authors, Spranger could see in the "young teacher" a "pedagogical enthusiasm" at work, which is founded in a "mysterious riddle". This teacher feels "intertwined with the very depths of the world" (Spranger; in: Fontana, 2010. 25. p.). He is animated by an "indelibly hot love for our people" (Spranger; in: Fontana, 2010. 50. p.), and understands his service as an "actual divine service" (Spranger; in: Fontana, 2010. 25. p.). - On the genesis and systematic position of the "supraindividual spiritual powers" quoted by Spranger and many other thinkers there would be still many things to be added. Already in the term "supraindividual spiritual powers" itself lies the appeal for unconditional subordination under these powers. - As an individuation of the "objective spirit" respectively of the "supraindividual spiritual powers" the idealistically minded pedagogue and philosopher enlightened by those powers can recognize himself, and without hesitation he in the horizon of Great Goals may remind of altruistic services, in certain historical-political contexts also of military service and corresponding preparatory educational arrangements. - Unlike some of his colleagues, however, Theodor Litt was able to adopt an explicitly critical attitude towards fascism while courageously accepting personal disadvantages (Cf. Ortmeyer, 2009; Matthes, 2011; Skiera, 2018).

It becomes apparent that GP is reluctant to accept the philosophical consequences of its own approach. To the greatest possible extent, it refrains from a historicizing deconstruction or a relativization of absolute theorems founded in transcendence and apodictic-authoritarian postulates. Thus the difference, the contradictions are overcome and harmonized; and the "miracle" of binding and liberating education (see above) can happen.

But in contrast to important concepts of reform pedagogy - such as those of Montessori, Steiner and Blonsky (see below) - the GP does not connect its transcendental foundation with a concrete evolutionary or revolutionary utopia. It leaves the future largely in the open. Despite the authoritarian moments, this ensures that the actors on the stage of education have a certain theoretically legitimized scope for decision-making and action.

With regard to educational theory, this also means a certain connectivity to a critical, non-dogmatic discourse in the field of educational philosophy. 


\section{Excursus: Wolfgang KlafKi (1927-2016) AND His "CATEgorical EDUCATION" AS A TRANSCENDENTAL-EMANCIPATED CHILD OF THE IDEALISTIC HEALING FORMULA OF LITT'S COINAGE}

It was only Theodor Litt's (and Erich Weniger's) student Wolfgang Klafki who, by means of dialectical-hermeneutic analysis, historically seen after walking through the purgatory of American "re-education" and on the soil of the liberaldemocratic Federal Republic, found a new term - first in 1957: that of "categorical education". With the historicization of previous educational theories (the socalled material and formal ones), this concept leaves the transcendence reference (largely) behind and places the task of mediation between individual/person and society/culture completely in the (democratic) here and now, of course, still in the horizon of the reconciliation of opposites. With this - nevertheless the foundation stone was laid for the development of what Klafki later called the critical-constructive educational science, with the help of which he wanted to record, make conscious and save the "good" sides of idealism, so to speak its enduring philanthropic face, for future generations and discussions - while its problematic and tendentially martial flip side was largely allowed to fall by the wayside. Klafki's reconciliatory and conciliatory attitude can also be found towards reform pedagogy (the "New Education"), the potential of which he defended for stimulating pedagogical reforms against the numerous general and fundamental critics of reform pedagogy, and which he also "constructively" brought to support numerous school experiments.

Klafki's work became perhaps the most important stimulus and reference in the didactic discussion in the German-speaking countries, above all through the development of "constructive" guidelines for contemporary school work and curricula. Here are just a few keywords: the "didactic analysis" with its five basic questions (cf. Matthes, 2011. 88. p.) and later the definition of the "epochal key problems", which should gain great influence on all curricula in the Federal Republic of Germany, furthermore its concept of general education which was strongly inspired by Comenius, its theory of the elementary and the definition of competences such as critical ability, empathy, networked thinking and others.

If we consider Klafki's educational formula, it becomes clear that its structure and content are based on Litt's formula; the idea of reconciliation is still to be found, aiming at a quasi-mystical experience of unity in the act of encounter between the subjective and the objective, in the "becoming aware" of "unity", as well as the high respect for the objective; but it also becomes clear how Litt's "maximum formula" has changed and developed into one that, because it no longer refers to an absolute objective, only to an objective that has become historical and "given", opens itself up to the contemporary philosophical discourse of education, thus decisively enlivening it. It argues phenomenologically and dialectically: "We call education that phenomenon in which - in our own 
experience or in the understanding of other people - we directly become aware of the unity of an objective (material) and a subjective (formal) moment. The attempt to express the experienced unity of education through language can only succeed with the help of dialectically entangled formulations: Education is the opening-up of a material and mental reality to a human being - this is the objective or material aspect. But at the same time this means: the human being's opening-up to the reality of his/her own - this is the subjective or formal aspect at the same time in the 'functional' and 'methodical' meaning." And further, related to the process of education: "Corresponding applies to education as 'process': Education is the epitome of processes in which the contents of a material and spiritual/mental reality are opened up and this process is - seen from the other side - nothing else than the opening up of a human being to oneself or being opened up to those contents and their connection as reality. This double-sided development takes place as the visibility of general, categorically illuminating contents on the objective side and as the rising of general insights, perceptions, experiences on the side of the subject" (Klafki, 1963. 43. p., italic by W.K.; see also: Matthes, 2011. 74. p.).

This is certainly an educational formula that was born in pain, but which idealism must provide for anyone who seriously wants to continue it and "save" its good sides. After all, the pain becomes transparent. It is not without good reason and not without pride that the humanities repeatedly speak of "the effort of the term" (Hegel). Who - in Hegel's sense - wants to grasp the "whole" (in the mind), and to clarify from this overall understanding the essence of a singular fact, i.e. to bring it "to the concept", to understand it and to make it understandable for others, obviously cannot do without "dialectically entangled formulations", which, as Klafki probably suspected, would not only cause him, but also the following student teachers, some headaches. In any case, this new piece of art from the workshop of idealism must have pleased every teacher of Klafki, as well as the post-war community of GP as a whole.

But what about the concept of education today that is in love with unity? Klafki's formula also remains closely related to Litt's, which is about theoretically unifying the opposites in the expectation that reality should be guided by them, or rather - not blind to real events at all - that the hopeful signs (such as the Unity School, later the Comprehensive School, and tendencies towards progressive democratization after 1968) will multiply and come into practice. Of course, measured against the great aspiration, this can never really succeed.

\section{Maria Montessori - Education as AN Introduction to the COSMIC LAW OF DEVELOPMENT}

Montessori's pedagogy is designed to give the child the opportunity to follow independently and freely the path of his inner development plan. Her educa- 
tional concept is based on the idea of the "normalized" child, who has found connection to his "nature", to his law of development anchored in the divine will or in the cosmic plan which can be scientifically discovered. Normalization according to the specifications of the inner blueprint is the actual (cosmic) task and "work" of the child. This event becomes visible as a development, which is individual in each case, but according to a phase plan that is uniform for all.

The development is characterized by different time-definable sensitive periods, in which the child is particularly disposed for the education of certain physical, mental and moral abilities. The current disposition shows itself in a particularly deep interest in a thing or an activity, namely in the increased concentration or polarisation of the child's attention. The focus on an activity is accompanied by a state of calm, inner order, satisfaction, which leads the child to "goodness". Failures in a sensitive period lead to damaging deviations; these are deviations from the path of normalization, the consequences of which can only be compensated with difficulty and sometimes not at all. This results in the high responsibility of the educator. He/she has to provide the special means of a normalizing education. This includes centrally: the prepared environment, the exercises of practical life and the development or Montessori material. In an appropriately "prepared environment" the child soon shows an increased, deep inner concentration, visible above all in the correct use of the Montessori material and in the "practical life exercises".

Since Montessori's "discovery of the child" in the "casa dei bambini" in Rome in 1907, the so-called Montessori phenomenon, the "polarisation of attention", has been observed in Montessori institutions worldwide. At the same time, this is the key to "normalising the society of adult people" (M, 1980. 287. p.). Education based on the inner blueprint wants to "bring salvation". It follows a universal curriculum "which can unite the mind and conscience of all people in harmony ..." (M, 1979. 139. p.). Montessori's vision is a "super-organism made up of humanity". The possibility lies in the "biological liberty" $(M, 1913$. 477. p.); in the "free and peaceful development of life" itself. The direction of this "free" development lies in the "horme" defined as the "divine" or "universal power" inscribed in evolution. This force is identified by Montessori with what is principally good $(M, 1949$. 123. 375. p.), while evil and the devilish, wherever it may appear, do not belong to this universal force. To lead the child onto the path of this higher power or to let this driving force inherent in the child work its way through - that is the actual task of the teacher.

For the child, following this path means a spontaneous, natural order or discipline. The child finds in the "prepared environment" only what he/she wants in the depth of its being anyway; he/she finds to himself/herself, namely to the path of development of his or her "normalization". The pedagogical dilemma no longer exists, the gap between willing and desired is bridged, the unspeakable struggle between child and adult ends, the contingency of the educational is overcome. 
The transformational nucleus of the "prepared environment" is formed by the Montessori materials. This material is the condition for the "polarization of attention", i.e. the individual development, and at the same time the most important fuel in human history. It functions as the "key to the world", represents the cosmic order, holds the spiritual food of the child ready in itself, which is absorbed by the "polarized" child - and only by him - through the right, precisely prescribed use of the means.

In the Montessorian-style pedagogical space - qua conception - the profane, the pleasurable and the creative have only limited space. It will become the pedagogically through-and-through regulated incubation space of a future better world, which will one day be inhabited by maximally "normalized" individuals. Montessori also emphasizes the child's "love for the environment" ( $M, 1949.139$. p.); and she believes that the children become "like the thing they love." (146. p.). Behind this we find a (mechanistic) conception of development and upbringing that basically knows no free statements on the part of the child with regard to external influences and pedagogical interventions.

The child's possible resistance, his or her "no" to the pedagogical offers or his or her refusal or inability to enter into the quasi-meditative state of consciousness of polarisation can only be regarded as a sign of socially conditioned deviation insofar as there are no hereditary causes. This resistance caused by deviation must be broken for the salvation of the child and of mankind. If Montessori can nevertheless confidently say, "the children in our schools are free..." (M, 1972. 220. p.), this statement must - with knowledge of the eschatological background and the technical concept of education - therefore be supplemented by the phrase: as long as the laws of normalisation are respected and followed. In the case of deviation, resistance to its negative effects is appropriate as well as demanded - up to the destruction of the "bad" (cf. M, 1972. 242. p.). - Here the sceptic and ethicist would have to investigate, and to ask about the (un)human costs of such an approach, if it would actually be feasible and effective.

\section{Rudolf STEINER'S CONCEPT OF EDUCATION IN THE LIGHT OF THE "SPIRITUALIZATION" OF THE HUMAN BEING}

Despite some affirmative references to non-Christian ideas (e.g. during her stay in India), and despite her flirting with Italian fascism for more than a decade, Maria Montessori remained closely attached to the faith of her childhood, Catholicism. Rudolf Steiner, who was also a Catholic, remained a member of the church throughout his life. He is the founder of an own, holistic world view: anthroposophy. This is the basis of Waldorf education and the Waldorf School.

Anthroposophy refers to an esoteric world view, the most important axiom of which can be described as "the great all-embracing identity". Everything is contained in the Great One, and everything is vice versa identical: above and 
below, small and great, space and time, life and death, moment and eternity, being and becoming, near and far - or expressed in a mathematical formula: $\mathrm{a}=$ $b$, whatever $a$ and $b$ may be in themselves on a logical or empirical level. The $a$ priori of knowledge and thought, the rational "discriminating" (Gerd Brand), is suspended on the spiritual level. This fundamental overriding makes a discourse between the faithful and the unbelievers (or in anthroposophical speech: the "outside critics") that is supported by sensory empiricism and committed to (traditional) logic difficult, because the difference and contradictory (on the logical empirical level) in "truth" or in a higher, esoteric (or cosmic-spiritual) sense does not exist at all.

As a reaction to the reflection on the epistemological validity criteria of their statements repeatedly called for by the "outside critics", anthroposophy bases its esoteric understanding of the world on a specially developed epistemology, namely on an autistically self-referential one which cannot accept a validity criterion outside of its own. Ultimately it is based on the acclaimed vision of the seer (i.e. Steiner) as a human being gifted by the "ruling being", thus a person who has direct access to this very "ruling being" of the cosmos. This is the reason for Rudolf Steiner's extremely creative-associative, sometimes systematic, then again narrative language. At the same time, the axiom of the One is repeatedly overridden when individual phenomena (animals, things, human races, peoples, individual - e.g. unpleasant - persons, etc.) are placed more or less advantageously on the hierarchical ladder of the Spirit. Somehow, however - at least on the level of linguistic communication - the annoying differentiations are needed as a basic condition of discourse, decision and action; especially in our world of political and theoretical conflicts, in which it is indispensable to identify the opponents or enimies of one's own project.

Even more clearly than with Montessori, the child and his or her teacher enter a sacred space with the Waldorf School in which - ultimately - the encounter with and the transformation of the child's spirit with the spirit of the cosmos is at stake. This is conveyed through architecture (avoiding the right angle according to an organic model) and a special, spiritually effective colouring, as well as through the encounter with the teacher who is already further advanced in the spiritual. For Steiner, the teacher is nothing less than the representative of the cosmos and the spirit working in it. His service is "altar service", and the teacher - again in contrast to Montessori, where he or she works rather indirectly and from the background - has an explicitly leading role.

The Waldorf School's connection to anthroposophy is also visible in its own highly developed aesthetics. Its concrete model is the anthroposophical temple building in Dornach (Switzerland), the "Goetheanum", which is built according to special aesthetic (organological, "Goethean", special colour and form theoretical) principles. These principles are reflected in almost all buildings that are committed to anthroposophy or close to it, as well as in school architecture and equipment. In this respect the talk of school as a sacred space and appendix 
of the anthroposophical "church" is entirely appropriate.

This also means that the school cannot be seen and understood in its own right. For it is integrated into an overarching spiritually permeated cosmos. Its use is not specifically recommended to the pupils and their parents, but it is open to all believers and interested persons as a spiritually permeated cosmos of anthroposophical character. Anthroposophy actually succeeds in producing a synthesis, convincing for many people, of almost everything that is still articulated today in the environment of alternative forms of life, beginning with questions of tillage and agriculture, proper nutrition, natural healing methods, the social constitution, the economy and the world of work, art and architecture, Christian-religious or spiritual renewal, education from preschool to university.

Thus an incomparable cosmos, a spiritually loaded space, as it were a special "spiritual territory" has emerged, an alternative anthroposophical parallel world, often networked with the rest of the world, in which all aspects of human life from the cradle to the grave and far beyond are placed in a uniform horizon namely that of the universal cosmic work of the Spirit.

Particularly important for concrete life are the corresponding social and pedagogical institutions, which together form a networked system of effectively working organisations. The anthroposophist sees in the existence and further development as well as in the practical successes an empirical confirmation of his teaching, seeks this confirmation and public recognition also by cooperation with external experts and empirical researchers. Anthroposophy is the philosophy and practice of life; life-reform, social reform and educational reform par excellence (Detailed in: Skiera, 2010 and 2018).

\section{PAVEl P. Blonsky AND his "INDUSTRIAl WORK SCHOOL" - EDUCATION AS "ANTHROPOTECHNICS" AND "SOCIOTECHNICS"}

The observer can enter the Waldorf and Montessori schools and explore the question of how the transcendental normative or sacred of concepts manifests itself in the architecture, in the furnishings, in the teaching-learning process and in the atmosphere. Blonsky's conception is different; unlike the other two, it has not been intentionally implemented in hundreds of schools. There is no definitive Blonsky school. Nevertheless, the influence of his ideas can hardly be overestimated, especially in the sphere of socialism/communism, and here again in the establishment of the so-called "Polytechnic High School".

Blonsky's work can be located in the horizon of socialist-communist aspirations and their fundamentalist axiomatics, in the conviction that the historical development after a dialectical process of militant confrontations finally leads to a peaceful world community of the happy equals. His educational goal, if one wants to speak in ancient images, is the final synthesis of Sparta and Athens, of power and spirit in the "worker philosopher". 
Blonsky sees his merit and his contribution to the development of the new man and the new society in creating the pedagogical preconditions for this development to perfection. The most important means for him is the creation of a "work school" oriented towards industrial work. Its specific character is already prepared in the "preschool education" and the "school of the first stage" (for the age group of 8 to 17) by various references to industry and the (mythically exaggerated and mystically charged) man-enhancing power of the machine. In the "second stage school" (for the fourteen to eighteen year olds) the educational space is then explicitly extended to industrial production in the factory.

The educational conditions go hand in hand with political decisions. For the Bolsheviks, their goal is to achieve "the perfect congruence of production conditions and productive forces" (Stalin, in: Glucksmann, 1976, 105. p.). To this end, Lenin issued the order soon after the October Revolution to "cleanse the Russian soil of all harmful insects". (Lenin, ibid., 83. p. - Blonky: Skiera, 2010 and 2018 in detail) - Above all in this martial basic feature, the ideology of the annihilation of the opponent - with all the necessary differentiation - the structural correspondence between socialism/communism and fascism becomes clear (Cf. Kroll et. al., 2014).

Blonsky's conception reflects some of the belief of all reform educators in the power of proper education in general and the pedagogical concepts of activity and self-activity in particular. For Blonsky, this goes hand in hand with the attempt to demonstrate the dialectics of emancipatory subject genesis and social development in a materialistic generic-historical perspective in the medium of work and to make it pedagogically fruitful.

The "worker philosopher", i.e. the reconciliation of the worker with the intellectual in the individual himself and in society, remains, of course, with Blonsky an educationally uncertain fiction, because he does not really succeed in constructing a uniform curriculum and educational space that is tailored to industrial work. Thus it is once again the grandiose, politically initially supported attempt to think "holistically" about the world as a whole and to represent it curricularly. For him, his "industrial work school" is the "village and state of the future" $(B, 1973$. 25. p.). His attempt has the character of an eschatological doctrine of salvation of quasi-religious character with all essential components of such a doctrine, including a paradisiacal vision of this world. On the one hand, there is the all-encompassing cause, the industry, as the crowning glory of creation, i.e. of history, which promises equality among men and happiness for all. And there is the Messiah, the builder of the unified world to come: the child as the little industrialist who, after the annihilation of capitalism, has absorbed the concerns of his people and of the "labouring humanity" (143. p.) as a whole with an altruistic heart and lives for them. He has become a Narodnik, a teacher of the people, "into the bones" (142. p.). Our little Narodnik emerged from the factory, in which not only machines produce new goods and new machines; for in the production process and through it man forms himself 
as a New Man of a higher kind. Blonsky: "The factory is nothing more than a very distinct organism, a 'structured machine system'. As such, it is an ideal cooperation of labor forces, and the regime of the factory is the regime of a maximally socialized cooperation disciplined by the production process itself. The factory creates a closed working organism out of the individual workers" ( $B$ in: Hierdeis, 1973. 94. p.).

Thus the human being is ultimately reduced to the individual worker or the industrialist. His home is the factory, which socializes "inevitably", i.e. automatically and naturally ("organism"). The factory becomes the sociotechnical and anthropotechnical delivery room of the New Man and the New Society. The unmistakable sign of subjectivity, the contradiction against industrial integration, can only appear as the outgrowth of a pathological egoism (lack of altruism) to be treated pedagogically and, if necessary, therapeutically, or as a false (class) consciousness.

\section{SUMMARY, DISCUSSION, CONCLUSION: EDUCATION UNDER THE RULE OF SURROGATES OF THE SAINT AND TRANSCENDENTAL-ABSOLUTE CONTROL POWERS}

Due to its transcendental claim to validity, the ideal image of the educator and the education drawn by the relevant authors has a special character, which is often overlooked, misjudged in its constitutive function or simply ignored.

The "Geisteswissenschaftliche Pädagogik" sees in the teacher the mediator of eternal, supernatural values. His or her tools are the curricular distillates of the (historically grown) culture, which in turn are permeated and interwoven by the "objective spirit" - as a substitute for the old Holy Spirit. The distillates themselves, though necessarily culture- and thus "time-bound", are then also shaped by the "objective spirit". This is the actual driving force of the educational process. The "eternal values" of the "objective spirit" are nevertheless mediated through the profane contents - as into these deeply embedded spiritual elements which are intended to serve the higher human education by being brought to "shine" (Litt - see above) in the pupil.

So, to give a concrete example, the learning of the old or new languages is not - or at least not only - about the development of new language skills, which everyone could then use for good or bad purposes according to his will, but it is above all about the education and moral consolidation of man and the human community; in other words: it is not (only) about communication, but ultimately about communion or the quasi-mystical unification with the principally good world spirit and - in social regard - about the possibility of social cohesion connected with the internalized good.

Thus the "objective spirit" does "its articulating work on the still shapeless souls" (Litt - see above). The purpose and goal of this work is to educate the 
good man, a man who knows and feels committed to the true, the good and the beautiful. For this moral Trinity, not the wrong, the bad, and the ugly, contains in itself the essential ingredients of the "objective spirit". The new Trinity of the par excellence of good represents the "unum bonum" of the all-embracing Being and God. In education it must therefore be a matter of bringing these truths closer to the pupil, if necessary also with coercive means (In this context Spranger once speaks of the "pedagogical thrust" into the heart of the pupil. - Spranger, 1958. 44. p.). At the same time the GP as such (i.e. insofar as its representatives are aware of its historicity and remain bound to a universal Christian ethics) shows a certain restraint in the definition both of the human being and of concrete social or human goals. Thus, despite its "absolutistic" rhetoric, it leaves the future largely in the open. Thus the GP - until today remains connectable in the field of the philosophical discourse of education.

This restraint is abandoned by the messianic authors of reform pedagogy. Their views of the world and their associated theories of education are based on a closed anthropology, a teleological doctrine of development and an eschatology turned into this world.

Montessori and Steiner, for example, determine the character of the new educator in emphatic words in a way that, apart from the special religious connotation, applies in principle to almost all authors of the new "Century of the Child" (Ellen Key). Montessori says: "The power of vision of the teacher must be at the same time exact as that of the scientist and spiritual as that of the saint" (M, 1976. 131. p.). Rudolf Steiner speaks of the "altar service", of the "religious cult" of the educator (GA, 293. 206. p.; GA, 298. 23. p.). "The teacher must in a certain way be a prophet," for he has "... to do with what is to live in the future generation, not in the present" (GA, 298. 28. p.).

The transcendental or crypto-theological foundation of the educational theories dealt with here thus has its own specific character. If we illuminate the areas of the theories lying today in the "shadow" of their half-forgotten history, the following can be said with regard to their crypto-theological orientation.

The "Geisteswissenschaftliche Pädagogik" is based on the "superior violence" of the "objective spirit", which historically can be seen as a substitute of God (or more precisely: of the Holy Spirit). Thus one could with a wink certainly speak of the "Heiliggeist-Wissenschaftliche Pädagogik" (Holy Spirit Scientific Education), and at the same time would have to admit that the called spirit is not very precise both in its originally holy and historical-profane form, and thus remains quite "open" for new questions and new challenges.

For Montessori, the cosmic plan of salvation (the "blueprint") functions as a substitute for God. This is, as it were, materialized in the Montessori material, embedded in the "prepared environment" and personified in the educator saint with a Montessori diploma.

In Rudolf Steiner's pedagogy God comes along as Cosmic Spirit, "ruling being" or physio-spiritual evolution (detailed in Skiera, 2018. 145. p.). "God" 
or/and His substitut forms have materialized in the aesthetically-rhythmicallyartistically designed "time-space" of anthroposophically determined education and personified in the educator.

In Blonsky and in Communism/Bolshevism God has now been completely removed from his classical function - but only rhetorically and apparently. For here too there is an unconditional pseudo-divine substrate without which the sociotechnical and anthropotechnical world of the industrial working school cannot exist. It is the machine and the factory.

What does the new scientifically trained educator saint see in the child and how does she understand her task? She sees many things, certainly also stimulated by her special training, which have been discovered in the pedagogical discourse since Plato and methodically implemented in many cases: she knows about the importance of play, activity, the vividness of teaching, the developmental appropriateness of her (teaching) words, about an appropriate, friendly environment, about good human relationships and so on. However, the new educator now recognizes much more with her deep view into the soul and into the essence of the child, and that is the specific and conceptually decisive in each case in comparison to the representatives of the Old Education of religious or authoritative-state provenance. Due to the relatively concrete teleological signature of the reform pedagogical concepts mentioned here, their view extends further than that of the "Geisteswissenschaftliche Pädagogik". The educator saint recognizes in the child the unmistakable signs and glimmers of hope of her hitherto futile longing for wholeness, beauty, happiness, harmony, meaningfulness and peace. She thus recognizes herself. The child becomes the mirror of her own soul. And she also recognizes herself in the resistant child, whose soul saving is one of her high tasks.

The communist Blonsky educator, for example, sees in the child the future altruistic worker-philosopher, who is working on the further optimization of the organically interconnected individual collectives of people with equal rights and duties towards a forever peaceful global human collective - a maximally socialized human organism.

The evolutionary Montessori educator sees in the child the dawning of a uniform, peaceful "super-organism made up of humanity", which can only be achieved by the child's precise tracking into the path of normalization - inscribed into the child by divine natural law.

The Rudolf Steiner educator, who is familiar with the spiritual world, who believes in the Spirit and who is connected to the cosmic powers, i.e. trained in anthroposophical spiritual science, beholds in the child basically a transitory spiritual being which is still for the time being enclosed in various covers or "bodies" - among them also a lower "physical body" (Steiner, 1989. 137. p.). This individual spirit being walks on the path, which has already lasted for thousands of years and is still about four to five thousands of years long and which is closely connected with the cosmic development, into the trans-sensory, thus at 
the same time trans-material and trans-human overworld of the Spirit. Now equipped with a special spiritual sensorium and at the same time with creative omnipotence, the spiritual essence of man experiences its final redemption and dissolution, which is equivalent to the complete disposal of its individuality and personality.

All these educators are "redeemed" in the sense that with a specific pedagogy a new horizon of meaning of life is opened to them, which the necessarily always limited scientific or state curricula cannot offer yesterday or today for many understandable reasons.

The individual child with its individual possibilities, limits and possibly contradictory needs, as well as the educator as a struggling but nevertheless fallible human being, is thus sacrificed on the altar of higher, teleologically justified, ultimately undeniable human goals in favour of a super- or overchild or a super- or overeducator. The stomachs of the Absolute feed on the abandonment of the individual and the subjective. The superhuman is the enemy of the small needy ego. The Great Idea is the enemy of everything imperfect, the transformation and subordination of which it must demand.

By their missionary commitment the educator-reformers wanted and want to free people and humanity from the constraints of the old education and at the same time from the horrors of the old world. They and their followers are undoubtedly convinced and fulfilled of the correctness, universal meaning and truth of their mission. But they have a cosmos of totalitarian constitution. For the educator-saint no longer acts in the name and within the framework of human necessities and in the mode of ever fallible human efforts. He/she has a special task and position qua function and mission. He/she is now the representative of a historically necessary, cosmic, divine or teleological-eschatological power of control, whose all-encompassing mode of action he/she himself/herself recognizes and acknowledges. Thus, if we theoretically consider the ultimate consequence, the educator works, contrary to his/her declared intention, on alienation, ultimately on the release of man from his humanity. - In the eyes of the believer, of course (i.e. from an affirmative inner viewpoint), this is the fulfilment of man and the history of mankind, thus the final victory of light over the mighty forces of darkness.

Again it is Montessori who bluntly expresses the educational attitude implied therein, and who certainly finds the applause of all those who believe and work on their own vision of a New World: "We must take as our instrument the child" (M, 1949. 103. p.).

What does all this mean with regard to a child who enters into an educational environment optimally equipped according to the theoretical standards of its creators with a suitably prepared educator-saint; that is: entering into the "prepared environment" adapted to his/her inner law of development (Montessori), into the utmost socializing communist educational collective (Blonsky) or into the special aesthetic and social world of anthroposophical imprint aimed at the 
child's spiritual life and his spiritualization, a world artistically designed in every detail through and through (Steiner)?

The flexible, adaptable and adaptive child, as well as the successfully adapted and adapting child after various curative treatments, will undoubtedly learn many good and interesting things, and will find himself/herself confirmed in his/her need for recognition; just as the effort of the educator will be confirmed by the successful adaptation. And the convinced theorist will also find himself and his theory confirmed.

The permanently unadapted, the disobedient or resistive child, on the other hand, experiences a lonely mental inner struggle between the will to assert oneself and the willingness to adapt, the possible external, situational and ideological causes of which cannot be recognized by the child himself or by his educator led by the "truth". The child is left alone and cannot find anyone who really wants to and can listen to him/her in a human way. The resistive self in the child and in the educator - as long as the latter shows resistance due to the insight into insurmountable limits of her actions or doubts regarding her previous convictions conforming to theory - has no place in the perfected cosmos.

The cosmos of Blonsky's imprint, in fact, aims at the social integration of the child forced and controlled by the collective; the Montessorian cosmos at the forced and permanently supervised tracking of the child according to the immanent divine regulation; the Steiner cosmos at the quasi-casual spiritualization of the child, by exposing the child to the ultimately undeniable effects of the Great Cosmic Spirit by means of sophisticated aesthetics and didactics.

In the decidedly teleological concepts there is no possibility to create an open, creative space for the creation of a pedagogy of dialogue, of participation in common affairs, of a pedagogy of conflict and of rational conflict resolution. Such a pedagogy cannot be theoretically justified in the three concepts of reform pedagogy outlined here, because an "open" pedagogy or a dialogical education cannot be founded on the recourse to absolute truths.

\section{BIBLIOGRAPHY}

Note on the works of Montessori and Steiner: Many works by M. Montessori and almost all by R. Steiner are digitally accessible on the Internet; Steiner: http://fvn-rs.net and http://bdn-steiner.ru, under the latter link also many facsimiles of transcripts of Steiner's lectures, some of which have not yet been published in print.

Referring to Montessori: https://archive.org.

Steiner is cited in the text above as GA (Gesamtausgabe - complete edition); Montessori as M, Blonskij as B. 
Blonskij, Pavel Petrovič (1973): Die Arbeitsschule. Vollständige Ausgabe und Neü̈bersetzung des ersten und zweiten Teiles. Besorgt von Horst E. Wittig. Ferdinand Schöningh, Paderborn.

Borst, Eva (2017): Kein Ort. Nirgends. Zu den Merkmalen utopischen Denkens, in: Németh et.al. (siehe dort).

Fontana, Michael (2010): „... jener pädagogische Stoß ins Herz“ Erziehungswissenschaftliche und biographisch-politische Kontinuitäten und Diskontinuitäten im Leben und Werk Eduard Sprangers. Peter Lang, Frankfurt

Glucksmann, André (1976): Köchin und Menschenfresser. Über die Beziehung zwischen Staat, Marxismus und Konzentrationslager. Wagenbach, Berlin.

Groys, Boris; Hagemeister, Michael (Hsg.) (2005): Die Neue Menschheit. Biopolitische Utopien in Russland zu Beginn des 20. Jahrhunderts. Suhrkamp, Frankfurt am Main.

Hierdeis, Helmwart (Hsg.) (1973): Sozialistische Pädagogik im 19. und 20. Jahrhundert. Klinkhardt, Bad Heilbrunn.

Klafki, Wolfgang (1963): Studien zur Bildungstheorie und Didaktik. Beltz, Weinheim.

Kroll, Frank-Lothar; Zehnpfennig, Barbara (Hsg.) (2014): Ideologie und Verbrechen. Kommunismus und Nationalsozialismus im Vergleich. Wilhelm Fink, München.

Litt, Theodor (1949): „Führen“ oder „Wachsenlassen”. Eine Erörterung des pädagogischen Grundproblems. Leipzig und Berlin (Erstauflage 1927).

Matthes, Eva (2011): Geisteswissenschaftliche Pädagogik. Oldenbourg, München.

Montessori, Maria (1913): Pedagogical Anthropology. Frederick A. Stokes Company New York.

Montessori, Maria (1916): L'autoeducazione nelle scuole elementari. Ermanno Loescher \& C, Roma.

Montessori, Maria (1949): The Absorbent Mind. The Theosophical Publishing House, Adyar.

Montessori, Maria (1972): Das kreative Kind. Der absorbierende Geist. Herder, Freiburg.

Montessori, Maria (1973): Frieden und Erziehung. Herder, Freiburg u.a.O.

Montessori, Maria (1976): Schule des Kindes. Montessori-Erziehung in der Grundschule. Herder, Freiburg/Basel/Wien.

Montessori, Maria (1979): Spannungsfeld Kind - Gesellschaft - Welt. Auf dem Weg zu einer "Kosmischen Erziehung". Herder, Freiburg u.a.O.

Montessori, Maria (1980) Kinder sind anders. Ullstein, Frankfurt u.a.O.

Németh, András; Stöckl, Claudia; Vincze, Beatrix (Hrsg.) (2017): Survival of Utopias - Life Reform and Progressive Education in Austria an Hungary. .: Peter Lang, Frankfurt a.M.

Ortmeyer, Benjamin (2009): Mythos und Pathos statt Logos und Ethos. Zu den Publikationen führender Erziehungswissenschaftler in der NS-Zeit: Eduard Spranger, Herman Nohl, Erich Weniger und Peter Petersen. Beltz, Weinheim und Basel. 
Pico della Mirandola, Giovanni (1486/1990): Über die Würde des Menschen. Felix Meiner Verlag Hamburg. (Philosophische Bibliothek, Bd. 427, lat.-dt. Ausgabe)

Protner, Edvard (2015): Die geisteswissenschaftliche Pädagogik in Slowenien zwischen Totalitarismus und Demokratie. Historia Scholastica, Prag, 1/2015.

Skiera, Ehrenhard (2010): Reformpädagogik in Geschichte und Gegenwart. R. Oldenbourg Verlag München und Wien. (1. Aufl. 2003)

Skiera, Ehrenhard (2018): Erziehung und Kontrolle. Über das totalitäre Erbe in der Pädagogik im Jahrhundert des Kindes. Klinkhardt, Bad Heilbrunn.

Spranger, Eduard (1958): Der geborene Erzieher. Quelle \& Meyer, Heidelberg.

Steiner, Rudolf (1989): Die Geheimwissenschaft im Umriss. Rudolf Steiner Verlag, Dornach. (GA 013)

Wellmer, Albrecht (1986): Ethik und Dialog. Elemente des moralischen Urteils bei Kant und in der Diskursethik. Suhrkamp, Frankfurt a.M. 